\title{
The Intermediate Role of Organizational Flexibility in the Impact of Using Information Technology on the Efficiency of the Application of IT Governance in Jordanian Industrial Companies
}

\author{
Hamzeh Mohamed Al-Hawamdeh ${ }^{1}$ \\ ${ }^{1}$ Asst. Prof. Jerash Private University, Jordan \\ Correspondence: Hamzeh Mohamed Al-Hawamdeh, Asst. Prof. Jerash Private University, Jordan.
}

Received: May 21, 2020

Accepted: June 21, 2020

Online Published: June 22, 2020

doi:10.5539/mas.v14n7p 75

URL: https://doi.org/10.5539/mas.v14n7p75

\begin{abstract}
The current study aimed to identify the intermediate role of organizational flexibility in the impact of using information technology on the efficiency of the application of IT governance in Jordanian industrial companies, the study population consisted of all Jordanian industrial companies which by the end of 2019 were (56) company. (23) company were excluded due to the lack of access to the necessary data for the study, bringing the study sample size to (33) company. Due to the small size of the study sample, all companies were taken with a comprehensive survey, and a random stratified sample was adopted to determine the size of the study sample in each company. Where the inspection unit included individuals working in the upper and middle administrative levels in Jordanian industrial companies. Multiple linear correlation test was used along with simple and gradient test , as well as Path Analysis using (Amos) And supported by the Statistical Package for Social Sciences (SPSS) program, the study reached many results, the most important of which was an indirect impact of the dimensions of the use of (information technology) combined ; in the efficiency of the application of IT governance with the presence of organizational flexibility as an intermediate variable among Jordanian industrial companies, as for the recommendations, it is necessary to find an organizational consistency between the uses of information technology in light of the use of COBIT 5 applications and guidelines in the presence of organizational flexibility, because it will help to adapt to unexpected crises and invest Opportunities for industrial companies at the local and global levels.
\end{abstract}

Keywords: IT governance COBIT 5, information technology, organizational flexibility

\section{Introduction}

Despite the novelty of the information revolution, it has succeeded in achieving radical changes at the level of society (individuals, companies). The recent years have witnessed a remarkable increase in the size of the integration of information technology in companies of all kinds. Pioneering systems and computer technologies were introduced in all of its activities and operations to take benefit from the competitive advantages resulting from the use of this technology, and to reduce time and cost on the other hand. And the fact that information is now a major resource for aspiring entrepreneurs, and a major catalyst for the performance of its multiple and diverse activities and operations, these companies, through the applications and tools of information technology, we're able to obtain the abundant and necessary amount of information in a timely manner, With the aim of supporting and assisting them in carrying out their various tasks (Zraqat, 2020). The rapid progress and development in the field of information technology, represented in the creation of IT governance and embodied in COBIT 5 technologies and organizational flexibility, had a great impact on the administrative operations of companies. First and foremost is oversight, which has led to fundamental changes in the methodology of oversight compared to what it was under traditional manual data processing, Where information technology has emerged of great importance in supporting the oversight role by relying on innovative business formulas, and by using the latest technologies, which contributed to providing the best supervisory services. Hence this study came to identify the intermediate role of organizational flexibility in the impact of using information technology on the efficiency of the application of IT governance in Jordanian industrial companies. 


\section{Problem of the Study}

In recent years, the world has witnessed rapid developments in all aspects of life. Among the most prominent of these developments is that in the field of information and communications technology, which has become a source of competition between companies, thus necessitated the need for companies to face the challenges and developments taking place today, by adapting their systems, developing, and working on proving its existence and maintaining its entity, in a way that guarantees it achieving its goals. Entrepreneurial companies, including industrial companies, have worked hard to keep pace with the progress and development in the field of information technology represented in the use of the governance of their own information technology through spending huge amounts of money on information systems and obtaining the latest technology in information and technology systems.

The study problem can be expressed by answering the following questions

1. Is there an effect of using information technology "IT" (software, hardware, and information security) on the efficiency of the application of IT governance in Jordanian industrial companies?

2. Is there an effect of using information technology " IT" (software, hardware, and information security) In organizational flexibility in Jordanian industrial companies?

3. Is there an effect of organizational flexibility in the efficiency of the application of IT governance in Jordanian industrial companies?

4. Is there an effect of the use of information technology "IT" (software, hardware, and information security) on the efficiency of the application of IT governance in the presence of organizational flexibility as an intermediate variable in Jordanian industrial companies?

\section{Study Hypotheses}

In light of the problem of the study and to answer its questions, the following hypotheses were formulated:

The First main hypothesis: H01: There is no statistically significant effect at the level of significance ( $\mathrm{P} \leq 0.05)$ of using information technology (software, hardware, and information security) on the efficiency of the application of IT governance in Jordanian industrial companies

The following sub-hypotheses arise from this hypothesis:

H01-1: there is no statistically significant effect at the level of significance $(\mathrm{P} \leq 0.05)$ of software on the efficiency of application of IT governance in Jordanian industrial companies.

H01-2: there is no statistically significant effect at the level of significance $(\mathrm{P} \leq 0.05)$ of Hardware on the efficiency of application of IT governance in Jordanian industrial companies.

H01-3: there is no statistically significant effect at the level of significance $(\mathrm{P} \leq 0.05)$ of information security on the efficiency of application of IT governance in Jordanian industrial companies.

The Second Main Hypothesis: H02: There is no statistically significant effect at the level of significance $(\mathrm{P} \leq 0.05)$ of using information technology (software, hardware, and information security) In organizational flexibility in Jordanian industrial companies.

The Third Main Hypothesis: H03: There is no statistically significant effect at the level of significance ( $\mathrm{P} \leq 0.05)$ of organizational flexibility in the efficiency of the application of IT governance in Jordanian industrial companies.

The Fourth Main Hypothesis: H04: There is no statistically significant effect at the level of significance $(\mathrm{P} \leq 0.05)$ of the use of information technology (software, hardware, and information security) on the efficiency of the application of IT governance in the presence of organizational flexibility as an intermediate variable in Jordanian industrial companies.

\section{Importance of the Study}

The importance of the study is reflected in the fact that it deals with a pioneering topic related to the use of information technology "IT" and its impact on the efficiency of the application of IT governance in the presence of organizational flexibility as an intermediate variable in Jordanian industrial companies.

As information technology using COBIT 5 has become today an indispensable necessity in various areas of life, and one of the most important basic resources that support companies in obtaining the necessary and vital information with minimal effort, cost and time, which will undoubtedly contribute to achieving efficiency and effectiveness in Its performance. 


\section{Literature Review}

There are many previous studies that dealt with the intellectual realities of the impact of IT governance (COBIT5), so we find the study of (Okour, 2019) that studied the impact of IT governance under COBIT5 framework on reducing the risks of cloud computing in Jordanian industrial companies, and to achieve the goals of this study, a Descriptive and analytical approach was used, The study community consisted of external certified public accountants practicing the auditing profession in Jordan, which numbered until the end of 2017 (384) as a practicing certified auditor, The study reached many results, the most important of which is the interest of the management of industrial companies in maximizing added value through the company's activities and operations and IT resources, and ensuring the optimal exploitation of it, and tightening control over the risks and threats of information technology. In addition to the efforts of the Jordanian industrial contributing companies to reduce the risks and threats generated by their use of technology and the extent of the efficiency and effectiveness of the procedures they follow in order to reduce those risks and reduce the size of their negative repercussions and the damage it causes to the company and its dealers, and to ensure The integrity and correctness of its data and information and maintaining it.

On the other hand, we find that (Ali, et.al 2019) study worked on studying the impact of information technology governance in light of the COBIT5 framework on the effectiveness of internal control systems in Jordanian industrial companies, and to achieve the goals of this study, a descriptive and analytical approach was used. The study community consisted of the employees of the accounting and financial departments and the internal audit unit in the Jordanian public shareholding industrial companies, which number is (65). The study reached many results, the most important of which was the presence of a strong and statistically significant relationship between the implementation of COBIT5 committee decisions represented in (planning, organizing, acquisition And implementation, providing service and support, evaluation and direct observation, monitoring and estimation) in the efficiency of the internal control system in industrial companies.

As for the study (Mutaiara..et..al, 2017), it worked to identify the system (COBIT) as the best standard for exercising oversight by the government in Indonesia regarding information technology and its evaluation, and this study used the hierarchical analysis process for a group of organizations and companies in Indonesia, The study showed that there are many benefits that result from using the COBIT system, the most important of which is the importance of control on information and technology for companies and organizations.

The study (Michele..et..al, 2017) worked to shed light on the evaluation of information technology systems using COBIT on all public shareholding companies, study community was represented in all joint-stock companies, the study sample represents (220) of its employees, the study concluded that the conceptual model of COBIT predicts the behavior of the auditor in the field, and who are auditing the results of the actions of those companies.

Finally, we find that the study (Al Kaabi and Quinn 2017) aimed to know the interactive role of administrative skills in promoting strategic leadership through organizational flexibility. For the Iraqi private banks, the study examined three important variables at the level of organizational and strategic thought (administrative skills, strategic leadership, and organizational flexibility) The researchers sought through statistical analysis to determine the nature of the relationship between them, the study tested through private banks in Baghdad on a sample of 44 individuals using the questionnaire form, which was designed according to a set of international standards and a set of statistical means was used, including: arithmetic mean, standard deviation, regression, and correlation. The study reached results, the most important of which are: Having private ownership of Iraqi banks for organizational flexibility, making them more able to confront the volatile environment and achieve their desired goals. As for the most important recommendations of the study, it is necessary for civil banks to focus on facing the challenges related to how they harness and develop the skills available to them to achieve harmony and complementarily between administrative skills, strategic leadership, and organizational flexibility.

\section{Theoretical Framework}

\subsection{Information Technology}

The world faces at the present time in light of the huge technological developments many great challenges, complex changes and continuous developments, and the issue of the survival, continuation and growth of companies in that atmosphere has become very difficult, which prompted attention to these challenges and changes, And focus on opportunities to deal with it properly as well as the uniting of various efforts and its integrity and consistency at all levels and paying attention to the information provided to it in terms of quantity and quality. As information is one of the most important strategic resources for companies (Ali et.al., 2019) and it is an important tool that contributes greatly to maintaining its survival, sustainability and continuity. 
Information is also one of the main sources from which companies draw the necessary and important facts and data that help them in taking appropriate measures and procedures to face the emerging conditions and changes and lead the company towards safety. Having access to appropriate information at the right time and with the lowest costs and in the easiest ways was considered one of the most prominent problems facing corporate management, however, thanks to information and communications technology and the great development in the field of computers and the emergence of networks and highways for information, organizations were able to overcome these problems. Through information technology, companies have been able to obtain the appropriate information that is accurate, modern, and reliable, and quickly, and to deliver it to all individuals and searchers whenever and wherever they are.

\subsection{The Concept of Information Technology}

The term information technology is one of the terms that lack a clear and specific definition for it, due to the difference in the fields applied in it and the angle through which information technology is viewed (Jawad and Al-Asadi, 2010, 7), In addition to the different environments and businesses that emerged through information technology (Al-Shanti, 2011, 336). The term was initially used in industrial fields, but it was soon expanded to include various fields of society.

Accordingly, the term information technology is a set of automated and electronic means necessary to perform basic business using the computer and through storage, processing and retrieval operations that are made on data and the dissemination of information for the purpose of benefiting from them in making specific decisions (Hamad and Saleh, 2018, 88), The researcher believes that information technology is a variety of devices, databases, software, computer networks and human experiences that are used to collect data, refine and purify it, and obtain useful information from it to provide adequate support to the company to carry out its functions and achieve its goals by providing help and assistance to decision makers in making appropriate decisions at the appropriate time.

\subsection{Information Technology Components}

Information technology provides, through its components, many different and various services that are related to the nature and activity of beneficiaries and patterns of their information needs. The information technology components are classified into:

\subsubsection{First: Software}

This component refers to the various programs that are used to run operations that process data and extract information. The software appears in the form of detailed orders (instructions) that control the operations of the information system and achieve three main functions: managing computer resources in the company, providing workers with the benefits of these resources, and mediating between the company and the stored information (Al-Rabiti, 2015, 30).

\subsubsection{Second: Hardware}

This component refers to the IT infrastructure, which includes the means and devices that support the work and help in accomplishing its tasks and achieving the goals (Al-Rabiti, 2015, 30), The hardware is considered one of the physical components used for input, processing, output and storage in the computer system, and therefore it contains six main components: the central processing unit, main and secondary memory, input technology, output technology, and communication technology.

\subsubsection{Third: Information Security}

They are all the necessary methods and procedures for storing information (Rommeny \& Steinbart, 2012, 30). With the increasing importance of information and the spread of complex computer systems in business, many companies have increased interest in making sure that information security applications allow them to access data in many cases, especially emergencies. This is provided by database management systems as it is able to protect data, disaster treatment and emergency planning (Alshareef, 2016, 367).

\section{COBIT 5 Concept}

(COBIT5) is a framework for managing IT risks which assists managers, auditors and users in understanding the IT systems that belong to their companies, as well as helps in developing the governance model and guides to choose the level of security and control necessary to protect companies' assets efficiently and effectively.

Therefore, you find that (Saleh, 2014) defined COBIT as : the control tool in information technology by searching for information that is the result of the unified use of information technology resources that need to be managed through information technology operations and for the purpose of meeting the company's goals. 
Whereas (Haddad, 2013,10) defined it as: a framework that allows the company to achieve the goals of governance and management in order to generate optimum value from information and technology, through maintaining balance within the desired benefits from risk management, controlling and achieving a balance between resources.

The researcher believes that COBIT 5 is: a standard framework consisting of a toolkit that helps corporate officials reduce the gap and reduce risks between information systems and the company's main business needs. The areas and controls of information technology according to COBIT 5 include the following (Romero et al., 2017; Iqbal, et al., 2016; Bakshi,2017):

1-Planning and organizing

2- Ownership and implementation

3- Support and delivery

4- Monitoring and evaluation

5- Guidance and control.

Therefore, the researcher believes that finding organizational consistency between the uses of information technology in light of the use of COBIT 5 applications and guidelines in the presence of organizational flexibility because that will help to adapt to unexpected crises and invest opportunities, therefore companies that have a high level of flexibility are more able to respond to conditions and events, This will also add value to industrial companies and reduce risks related to the use of information technology in them, This leads to creating better value for it through effective and innovative use of information technology, with an improvement in the relationship between business needs and information technology goals and increasing financial return by obtaining the largest value of investments in technology for Jordanian industrial companies.

\section{Practical Aspect}

\subsection{Study Methodology}

This study is considered a field study due to its being a study of Jordanian industrial companies, and in terms of its purpose is an Explanatory Study, as it depends on the causal relationship between the variables, and a deductive study, as it depends on previous studies and administrative theories, As for planning and controlling the study, it is non contrived, since it takes place in the natural environment of the organization without interference, and is considered cross-sectional in terms of the time horizon, as it is a one-time procedure and targets a sample at one time.

To achieve the goals of the study and answer its questions, the study relied on the descriptive analytical approach to describe the phenomenon under study, where a questionnaire was designed to measure the variables of the study, and to find the relationship between the variables of the study, analysis and interpretation with the aim of reaching generalizations with a meaning that increases and enriches the balance of knowledge on the subject, and building interpretations For data and information in order to obtain the desired results.

\subsection{The Study Samples}

The study population consisted of all Jordanian industrial companies which by the end of 2019 were (56) company. (23) company were excluded due to the lack of access to the necessary data for the study, bringing the study sample size to (33) company. Due to the small size of the study sample, all companies were taken with a comprehensive survey, and a random stratified sample was adopted to determine the size of the study sample in each company. Where the inspection unit included individuals working in the upper and middle administrative levels in Jordanian industrial companies.

\subsection{Analysis Unit}

The analysis unit consisted of the managers of the upper and middle departments in the Jordanian industrial companies who fall within the following job titles: General Director, Deputy Director, Department Director, and Head of Department. The researcher distributed (185) questionnaires to the study sample individuals, (174) questionnaires were retrieved, of which (11) were not analyzable, so that the number of questionnaires retrieved and subject to statistical analysis was (163), which is (88.1\%) of the total distributed questionnaires, which is a statistically acceptable percentage.

\subsection{Data Collection Methods}

The researcher relied in this study on using the descriptive analytical approach that starts from the organization's study throughout the research and field study method, and the researcher relied on two types of data sources to collect the data necessary to achieve the purpose of the study, which is as follows: 


\subsubsection{First: Secondary Sources}

The study relied on addressing the theoretical framework on secondary data sources in order to cover the subject of the study, its main variables, its sub-dimensions and indicative indicators. These sources were represented in scientific books, studies, articles and scientific journals, in addition to the relevant publications and statistics, with the aim of focusing on taking a general perception of the latest developments on the current study topics and their variables.

\subsubsection{Second: The Primary Sources}

The study relied on collecting primary data through a questionnaire, designed to achieve the purpose of the study, and in a manner consistent with the study problem and its questions, so that it covers all aspects that were discussed in the theoretical framework and the questions and assumptions on which the study was based, and for this, the questionnaire included two parts, the first includes general information Especially for respondents, and the second includes a set of paragraphs and phrases that reflect the questions, goals, variables and hypotheses of the study, and related to its dimensions and variables, to be answered by members of the study sample.

\subsection{Study Tool Stability Test}

The stability of the tool used to measure the variables included in it was tested using the Cronbach Alpha Coefficient test, where the scale result is statistically acceptable if the value of the Cronbach alpha is greater than $(0.60)$ (Sekaran, 2006, 311), and the closer the value is to $(100 \%)$ This indicates higher stability levels for the study tool, and given the data in the following table, the coherence factor alpha was measured for the variables of the study and for its dimensions and for the study tool as a whole, to find out the consistency of the answers, as follows:

Table 1. Reliability test of study tool

\begin{tabular}{ccc}
\hline Number & Dimension & Alpha value \\
\hline 1 & Software & 0.952 \\
2 & Hardware & 0.854 \\
3 & Information Security & 0.891 \\
& Using Information Technology & 0.956 \\
4 & Planning and organizing & 0.862 \\
5 & Ownership and implementation & 0.857 \\
6 & Support and delivery & 0.925 \\
7 & Monitoring and evaluation & 0.913 \\
8 & Guidance and control. & 0.881 \\
& IT governance & 0.977 \\
& Organizational flexibility & 0.953 \\
& All paragraphs & 0.987
\end{tabular}

We notice from Table 1 that the values of the internal consistency coefficient of Cronbach alpha for the study tool paragraphs ranged from (0.854-0.977), in addition to the fact that the value of alpha for all paragraphs amounted to (0.987), and therefore all values are greater than $(0.60)$ and this indicates an consistency between Paragraphs of the study tool and the reliability of the study tool for conducting statistical analysis.

\subsubsection{Multicollinearity Test}

To ensure that data is free of multicollinearity, the linear correlation coefficient was calculated for each variable, the results were as follows: 
Table 2. Multiple correlation matrix for independent variables

\begin{tabular}{ccccc}
\hline variable & Software & Hardware & $\begin{array}{c}\text { Information } \\
\text { security }\end{array}$ & $\begin{array}{c}\text { Organizational } \\
\text { flexibility }\end{array}$ \\
\hline Software & 1.000 & & & \\
Hardware & $0.721 * *$ & 1.000 & & \\
$\begin{array}{c}\text { Information } \\
\text { security }\end{array}$ & $0.647 * *$ & $0.658 * *$ & 1.000 & 1.000 \\
$\begin{array}{c}\text { Organizational } \\
\text { flexibility }\end{array}$ & $0.708^{* *}$ & $0.654 * *$ & $0.681 * *$ & \\
\hline
\end{tabular}

\section{(**) significant at the significance level of (0.01)}

Table 2 shows that the highest value of the correlation coefficient was found between the independent variables (hardware) and (software), which reached (0.721), which is less than (0.80), and this indicates the absence of the phenomenon of multiple linear correlation between the variables. Linear correlation coefficients above $(0.80)$ may be indicative of multicollinearity (Guajarati, 2004, 359). Therefore, it is possible to say that the study sample is free from the problem of multicollinearity.

To confirm the previous result, the variance inflation coefficient was calculated for each of the independent variables to ensure that there was no multicollinearity, and the results were as follows:

Table 3. Results of the multiple correlation test among the independent variables

\begin{tabular}{ccc}
\hline Variable & VIF & Tolerance \\
\hline Software & 2.684 & 0.373 \\
Hardware & 2466 & 0.406 \\
Information security & 2.249 & 0.445 \\
Organizational flexibility & 2.492 & 0.401
\end{tabular}

Table 3 shows that the values of the coefficient of variance inflation were all greater than the number 1 and less than the number 10, and the value of (Tolerance) was confined between the number 0.1 and the number 1 , which indicates that there is no problem of multiple linear correlation between the study variables.

\subsubsection{Autocorrelation Test}

One of the regression conditions is the absence of self-correlation problem in the data, which is defined as the existence of a correlation between the limits of random error in the regression model, which results in a bias in the value of the estimated parameters, thus weakening the model's ability to predict. This is confirmed by the most common and used Durbin-Watson Test, and the value of this test ranges between the numbers (0 and 4$)$. The existence of the self-correlation phenomenon is rejected if the value of (D-W) equals or approaches the number 2 (Gujarati, 2004, 496). The following table shows the results of the Durbin-Watson Test for the study hypotheses, as follows:

Table 4. Autocorrelation test

\begin{tabular}{ccc}
\hline Hypothesis & D-W Calculated Value & Result \\
\hline H01 & 1.802 & No Autocorrelation \\
Ho1-1 & 1.845 & No Autocorrelation \\
Ho1-2 & 1.932 & No Autocorrelation \\
Ho1-3 & 1.922 & No Autocorrelation \\
H02 & 1.966 & No Autocorrelation \\
H03 & 1.825 & No Autocorrelation
\end{tabular}

Note that the values of $\mathrm{D}-\mathrm{W}$ for the variables in all the Hypothesis mentioned are close to the number 2, which indicates that the data are free from the problem of self-correlation, that is, there is no correlation between the limits of random error in the regression model. 


\subsection{Description of the Characteristics of the Study Sample}

This part includes a description of the personal information of the study sample individuals: (gender, age, educational qualification, years of experience, and job title). In order to describe the characteristics of the study sample, repetitions and percentages of personal data were found for the members of the study sample, as follows:

Table 5. Description of the characteristics of the study sample

\begin{tabular}{cccc}
\hline Variable & Category & Repetition & Percentage \\
\hline \multirow{2}{*}{ Gender } & Male & 111 & 68.1 \\
& Female & 52 & 31.9 \\
\multirow{2}{*}{ Age } & 20 years- less than 30 & 27 & 16.6 \\
& 30 years - less than 40 & 41 & 25.2 \\
& 40 years - less than 50 & 62 & 38.0 \\
Educational & 50 years and more & 33 & 20.2 \\
qualification & Diploma or less & 6 & 3.7 \\
& BSc & 87 & 53.4 \\
& MSc & 43 & 26.4 \\
& Ph.D & 27 & 16.5 \\
Years of experience & Less than 5 years & 21 & 19.6 \\
& 5 years - less than 10 & 41 & 42.3 \\
& 10 years - less than 15 & 69 & 25.2 \\
& 15 years and more & 32 & 12.9 \\
& General Director & 7 & 4.3 \\
& Deputy Director & 14 & 8.6 \\
Job title & Department Director & 51 & 31.3 \\
& Head of Department & 91 & 55.8 \\
& Total & 163 & 100 \\
\hline
\end{tabular}

It is clear from Table 5 that the category (males) has formed the largest percentage of the members of the study sample, as their percentage reached (68.1\%), while the category (females) accounted for $(31.9 \%)$ of the study sample, and this may be due to the man's precedence for women To the job market, , Thus accessing managerial positions faster. The table also indicates that the members of the sample of the age group (20 years - less than 30 years) have formed the smallest percentage, as their percentage reached $(16.6 \%)$, while the other age groups formed larger proportions, and this corresponds to that access to administrative positions takes enough time periods . . In addition to that the( bachelor's )degree holders category formed the largest percentage of the study sample, which amounted to (53.4\%), followed by the (master's) degree holders group, which reached (26.4\%), and this is a clear indication of the high level of knowledge of individuals Workers in Jordanian industrial companies, and them possessing a reasonable level of scientific qualification. We also note from the table that the members of the sample from the experience category ( 5 years - less than 10 years) have formed the largest percentage of the study sample, reaching (42.3\%), and this corresponds to that access to leadership and management positions requires sufficient years of experience to perform the tasks And administrative duties assigned to administrative leaders. Finally, we note that the category (Head of Department) has formed the largest percentage of the study sample, which amounted to (55.8\%), while the category (General manager) formed the smallest percentage of the study sample members, which amounted to (4.3\%), and this corresponds to the Administrative pyramid in modern organizations, where the number increases as we go towards the base of the pyramid, and vice versa. 


\subsection{Analysis of the Study Tool Paragraphs}

\subsubsection{First: Description of the Independent Variable (Using Information Technology)}

Table 6. Arithmetic averages, standard deviations, ranks, and the relative importance of the dimensions of using information technology

\begin{tabular}{cccccc}
\hline Number & Variable & $\begin{array}{c}\text { Arithmetic } \\
\text { averages }\end{array}$ & $\begin{array}{c}\text { Standard } \\
\text { deviations }\end{array}$ & Rank & $\begin{array}{c}\text { Relative } \\
\text { importance }\end{array}$ \\
\hline 1 & Software & 3.877 & 0.834 & 3 & High \\
2 & Hardware & 3.974 & 0.580 & 1 & Hig \\
3 & Information security & 3.923 & 0.672 & 2 & High \\
Using information technology & 3.925 & 0.644 & & High \\
\hline
\end{tabular}

We notice from the previous table that the average for the use of information technology in terms of relative importance is high, as the general average reached (3.925) and with a standard deviation of (0.644). It came after (hardware) in the first rank with an arithmetic average of (3.974) and with a standard deviation of (0.580) along with high relative importance, while it came after (software) in the last rank with an arithmetic mean of (3.877) and with a standard deviation of (0.834) and with high relative importance.

\subsubsection{Second: The Dependent Variable (Information Technology Governance)}

Table 7. Arithmetic averages, standard deviations, ranks, and the relative importance of the dimensions of Information Technology Governance

\begin{tabular}{cccccc}
\hline Number & Variable & $\begin{array}{c}\text { Arithmetic } \\
\text { averages }\end{array}$ & $\begin{array}{c}\text { Standard } \\
\text { deviations }\end{array}$ & Rank & $\begin{array}{c}\text { Relative } \\
\text { importance }\end{array}$ \\
\hline 1 & Planning and organizing & 4.051 & 0.630 & 1 & High \\
2 & $\begin{array}{c}\text { Ownership and } \\
\text { implementation }\end{array}$ & 4.021 & 0.615 & 4 & High \\
3 & Support and delivery & 3.858 & 0.668 & 5 & High \\
4 & Monitoring and evaluation & 4.037 & 0.685 & 2 & High \\
5 & Guidance and control. & 4.023 & 0.588 & 3 & High \\
Information Technology Governance & 3.998 & 0.594 & & High
\end{tabular}

We note from the previous table that the average of IT governance in terms of relative importance is high, as the average reached (3.998) and with a standard deviation of (0.594). It came after (planning and organizing) in the first rank with an arithmetic average of (4.051) and with a standard deviation of (0.630) along high relative importance, while it came after (support and delivery) in the last rank with an arithmetic mean of $(3,858)$ and a standard deviation of (0.668) and with a high relative importance.

\subsubsection{Third: The Intermediate Variable (Organizational Flexibility)}

Table 8. arithmetic averages, standard deviations, ranks, and the relative importance of the dimensions of organizational flexibility

\begin{tabular}{cccccc}
\hline Number & Variable & Mean & $\begin{array}{c}\text { Standard } \\
\text { deviations }\end{array}$ & Rank & $\begin{array}{c}\text { Relative } \\
\text { importance }\end{array}$ \\
\hline 1 & Operational flexibility & 3.884 & 0.465 & 1 & High \\
2 & Human flexibility & 3.784 & 0.364 & 2 & High \\
\multicolumn{2}{c}{ organizational flexibility } & 3.834 & 0.359 & & High \\
\hline
\end{tabular}

We notice from the previous table that the mean for organizational flexibility in terms of relative importance is high, as the general average reached $(3,834)$ and with a standard deviation of $(0.359)$. It came after (operational flexibility) in the first place with a mean of (3.884) and with a standard deviation (0.465) and with a high relative importance, while it came after (human flexibility) in the second rank with a mean of $(3,784)$ and a standard deviation of (0.364) with a high relative importance. 


\section{Study Hypotheses Test}

In this part of the study we review the hypothesis test, where the first major hypothesis was subjected to the analysis of multiple and stepwise linear regression, and the branching hypotheses were subjected to the analysis of simple Linear Regression. The second major hypothesis was subjected to Multiple Linear Regression. Whereas, the third main hypothesis was subjected to Simple Linear Regression Analysis. The fourth main hypothesis was tested using Path Analysis using the Amos program and supported by the SPSS program to verify the presence of the direct and indirect impact of the study variables.

H01: There is no statistically significant effect at the level of significance $(\mathrm{P} \leq 0.05)$ of using information technology (software, hardware, and information security) on the efficiency of the application of IT governance in Jordanian industrial companies

The hypotheses derived from this hypothesis were subjected to simple linear regression analysis, and the results were as follows:

H01-1: there is no statistically significant effect at the level of significance $(\mathrm{P} \leq 0.05)$ of software on the efficiency of application of IT governance in Jordanian industrial companies.

Table 9. * Results of testing the impact of (software) on the efficiency of the application of IT governance

\begin{tabular}{|c|c|c|c|c|c|c|c|c|c|c|}
\hline \multirow[b]{2}{*}{$\begin{array}{c}\text { Dependant } \\
\text { Variable }\end{array}$} & \multicolumn{2}{|c|}{ Model Summery } & \multicolumn{3}{|c|}{ ANOVA } & \multicolumn{5}{|c|}{ Coefficients } \\
\hline & $\begin{array}{c}\mathrm{R} \\
\text { Correlation } \\
\text { coefficient }\end{array}$ & $\begin{array}{c}\text { R2 } \\
\text { Determination } \\
\text { Coefficient }\end{array}$ & $\begin{array}{c}\text { F } \\
\text { Calculated }\end{array}$ & D.f & Sig $F^{*}$ & Statement & B & $\begin{array}{l}\text { Standard } \\
\text { error }\end{array}$ & $\begin{array}{c}\mathrm{T} \\
\text { Calculated }\end{array}$ & $\begin{array}{c}\text { Sig } \\
t^{*}\end{array}$ \\
\hline $\begin{array}{c}\text { The efficiency } \\
\text { of application } \\
\text { of IT } \\
\text { governance }\end{array}$ & 0.724 & 0.524 & 177.588 & 1 & 0.000 & software & 0.534 & 0.040 & 13.326 & 0.000 \\
\hline
\end{tabular}

* The effect is statistically significant at the level $(\mathrm{p} \leq 0.05)$

The results of Table 9 indicate that the value of $(\mathrm{R}=0.724)$, which means that there is a positive relationship between (software) and (efficiency of application of IT governance). It turns out that the value of the coefficient of determination $\left(\mathrm{R}^{2}=0.524\right)$, and this means that (software) has explained $(52.4 \%)$ of the variance in (the efficiency of the application of IT governance), with other factors remaining constant. It also shows that the value of (F) has reached (177.588) at the confidence level $(\mathrm{Sig}=0,000)$ and this confirms the significance of the slope at the level $(p \leq 0.05)$ and at one degree of freedom. The table of coefficients also shows that the value of $(B=0.534)$ and that the value of $(\mathrm{t}=13.326)$ is at a confidence level of $(\mathrm{Sig}=0.000)$ and this confirms the coefficient significance at the level $(p \leq 0.05)$. Based on the above, we reject the first null sub-hypothesis and accept the alternative sub-hypothesis which state that : there is a statistically significant effect at the level of significance $(\mathrm{P} \leq 0.05)$ of software on the efficiency of application of IT governance in Jordanian industrial companies.

H01-2: there is no statistically significant effect at the level of significance $(\mathrm{P} \leq 0.05)$ of Hardware on the efficiency of application of IT governance in Jordanian industrial companies.

Table 10. * Results of testing the impact of (Hardware) on the efficiency of the application of IT governance

\begin{tabular}{|c|c|c|c|c|c|c|c|c|c|c|}
\hline \multirow[b]{2}{*}{$\begin{array}{l}\text { Dependant } \\
\text { Variable }\end{array}$} & \multicolumn{2}{|c|}{ Model Summery } & \multicolumn{3}{|c|}{ ANOVA } & \multicolumn{5}{|c|}{ Coefficients } \\
\hline & $\begin{array}{c}\mathrm{R} \\
\text { Correlation } \\
\text { coefficient }\end{array}$ & $\begin{array}{c}\mathrm{R} 2 \\
\text { Determination } \\
\text { Coefficient }\end{array}$ & $\begin{array}{c}\text { F } \\
\text { Calculated }\end{array}$ & D.f & $\operatorname{Sig} F^{*}$ & Statement & B & $\begin{array}{l}\text { Standard } \\
\text { error }\end{array}$ & $\begin{array}{c}\mathrm{T} \\
\text { Calculated }\end{array}$ & $\begin{array}{l}\text { Sig } \\
\mathrm{t}^{*}\end{array}$ \\
\hline $\begin{array}{l}\text { The } \\
\text { efficiency of } \\
\text { application } \\
\text { of IT } \\
\text { governance }\end{array}$ & 0.727 & 0.529 & 180.890 & 1 & 0.000 & Hardware & 0.717 & 0.053 & 13.450 & 0.000 \\
\hline
\end{tabular}

* The effect is statistically significant at the level $(\mathrm{p} \leq 0.05)$

The results of Table 10 indicate that the value of $(\mathrm{R}=0.727)$, which means that there is a positive relationship between (Hardware) and (the efficiency of the application of IT governance). It turns out that the value of the 
determination coefficient $\left(\mathrm{R}^{2}=0.529\right)$, and this means that (Hardware) have interpreted an amount $(52.9 \%)$ of the variance in (the efficiency of the application of IT governance), while the other factors remain constant. It also turns out that the value of $(\mathrm{F})$ has reached $(180,890)$ at the confidence level $(\mathrm{Sig}=0,000)$, and this confirms the significance of the slope at the level $(\mathrm{p} \leq 0.05)$ and at one degree of freedom. It also appears from the table of coefficients that the value of $(B=0.717)$ and that the value of $(t=13.450)$ is at a confidence level $(\mathrm{Sig}=0.000)$ and this confirms the significance of the coefficient at the level $(\mathrm{p} \leq 0.05)$. Based on the above, we reject the second null sub-hypothesis, and accept the alternative sub-hypothesis: there is a statistically significant effect at the level of significance $(\mathrm{P} \leq 0.05)$ of Hardware on the efficiency of application of IT governance in Jordanian industrial companies.

H01-3: there is no statistically significant effect at the level of significance $(\mathrm{P} \leq 0.05)$ of information security on the efficiency of application of IT governance in Jordanian industrial companies.

Table 11. * Results of testing the impact of (Information security) on the efficiency of the application of IT governance

\begin{tabular}{|c|c|c|c|c|c|c|c|c|c|c|}
\hline \multirow[b]{2}{*}{$\begin{array}{l}\text { Dependant } \\
\text { Variable }\end{array}$} & \multicolumn{2}{|c|}{ Model Summery } & \multicolumn{3}{|c|}{ ANOVA } & \multicolumn{5}{|c|}{ Coefficients } \\
\hline & $\begin{array}{c}\mathrm{R} \\
\text { Correlation } \\
\text { coefficient }\end{array}$ & $\begin{array}{c}\mathrm{R} 2 \\
\text { Determination } \\
\text { Coefficient }\end{array}$ & $\begin{array}{c}\text { F } \\
\text { Calculated }\end{array}$ & D.f & $\operatorname{Sig} F^{*}$ & Statement & B & $\begin{array}{l}\text { Standard } \\
\text { error }\end{array}$ & $\begin{array}{c}\mathrm{T} \\
\text { Calculated }\end{array}$ & Sig $t^{*}$ \\
\hline $\begin{array}{l}\text { The efficiency } \\
\text { of the } \\
\text { application of } \\
\text { IT governance }\end{array}$ & 0.775 & 0.600 & 241.987 & 1 & 0.000 & $\begin{array}{l}\text { Information } \\
\text { security }\end{array}$ & 0.699 & 0.045 & 15.556 & 0.000 \\
\hline
\end{tabular}

* The effect is statistically significant at the level $(\mathrm{p} \leq 0.05)$

The results of Table 11 indicate that the value of $(\mathrm{R}=0.775)$, this means that there is a positive relationship between (Information Security) and (efficiency of the application of IT governance). It turns out that the value of the determination coefficient $\left(\mathrm{R}^{2}=0.600\right)$, and this means that (Information Security) has explained $(60.0 \%)$ of the variance in (the efficiency of the application of IT governance), with other factors remaining constant . . It also shows that the value of $(\mathrm{F})$ has reached (241.987) at a confidence level $(\mathrm{Sig}=0,000)$ and this confirms the significance of the slope at the level $(\mathrm{p} \leq 0.05)$ and at one degree of freedom. Also, it appears from the table of coefficients that the value of $(\mathrm{B}=0.699)$ and that the value of $(\mathrm{t}=15.556)$ at the confidence level $(\mathrm{Sig}=0.000)$ and this confirms the significance of the coefficient at the level $(p \leq 0.05)$. Based on the above, we reject the third null sub-hypothesis, and accept the alternative sub-hypothesis: there is a statistically significant effect at the level of significance $(\mathrm{P} \leq 0.05)$ of information security on the efficiency of application of IT governance in Jordanian industrial companies.

To test the first major hypothesis, multiple regression analysis was used, and the results were as follows:

Table 12. * Results of testing the impact of (Using Information Technology) on the efficiency of the application of IT governance

\begin{tabular}{|c|c|c|c|c|c|c|c|c|c|c|}
\hline \multirow[b]{2}{*}{$\begin{array}{c}\text { Dependant } \\
\text { Variable }\end{array}$} & \multicolumn{2}{|c|}{ Model Summery } & \multicolumn{3}{|c|}{ ANOVA } & \multicolumn{5}{|c|}{ Coefficients } \\
\hline & $\begin{array}{c}\mathrm{R} \\
\text { Correlation } \\
\text { coefficient }\end{array}$ & $\begin{array}{c}\mathrm{R} 2 \\
\text { Determination } \\
\text { Coefficient }\end{array}$ & $\begin{array}{c}\text { F } \\
\text { Calculated }\end{array}$ & D.f & Sig F* & Statement & B & $\begin{array}{c}\text { Standard } \\
\text { error }\end{array}$ & $\begin{array}{c}\mathrm{T} \\
\text { Calculated }\end{array}$ & Sig $t^{*}$ \\
\hline The efficiency & & & & & & Software & 0.189 & 0.048 & 3.945 & 0.000 \\
\hline of the & 0.844 & 0.712 & 131.177 & 3 & 0.000 & Hardware & 0.247 & 0.065 & 3.800 & 0.000 \\
\hline $\begin{array}{l}\text { application of } \\
\text { IT governance }\end{array}$ & & & & & & $\begin{array}{c}\text { Information } \\
\text { Security }\end{array}$ & 0.401 & 0.054 & 7.430 & 0.000 \\
\hline
\end{tabular}

* The effect is statistically significant at the level $(\mathrm{p} \leq 0.05)$

The results of Table 12 shows that the correlation coefficient $(\mathrm{R}=0.844)$ indicates the relationship between the independent variables and the dependent variable, and the effect of the independent variables (using information technology) on the dependent variable (the efficiency of the application of IT governance) is a statistically significant impact, Where the calculated value of $\mathrm{F}$ was (131.177), and at the level of significance $(\mathrm{Sig}=0,000)$ which is less than (0.05), it appeared that the value of the determination coefficient $\left(\mathrm{R}^{2}=0.712\right)$ indicates that 
(71.2\%) of the variance in (the efficiency of the application of IT governance) can be explained by the variance in (using information technology) combined.

As for the table of coefficients, it has been shown that the value of B at (software) has reached (0.189) and that the value of $\mathrm{T}$ at it is $(3.945)$, and at a level of significance $(\mathrm{Sig}=0.000)$, which indicates that the effect of this dimension is significant. As for the value of B at (Hardware) has reached $(0.247)$ and that the value of $\mathrm{T}$ at it is $(3,800)$, and at the level of significance $(\mathrm{Sig}=0.000)$, which indicates that the effect of this dimension is significant. The value of B at (Information Security) was (0.401) and the value of T at it is (7.430), at a level of significance ( $\mathrm{Sig}=0,000)$, which indicates that the effect of this dimension is significant.

Based on the above, we reject the first main hypothesis and accept the alternative hypothesis : There is a statistically significant effect at the level of significance $(\mathrm{P} \leq 0.05)$ of using information technology (software, hardware, and information security) on the efficiency of the application of IT governance in Jordanian industrial companies.

To determine which dimensions of the (using information technology) had the most significant impact on (the efficiency of the application of IT governance), stepwise regression analysis was used, and the result was as follows:

Table 13. Results of the stepwise regression analysis of the first major hypothesis H01

\begin{tabular}{|c|c|c|c|c|c|c|c|}
\hline Model & $\begin{array}{l}\text { The efficiency } \\
\text { of the } \\
\text { application of } \\
\text { IT governance }\end{array}$ & B & $\mathrm{T}$ calculated & $\begin{array}{l}\text { Sig* } \\
\text { level }\end{array}$ & $\begin{array}{c}\mathrm{R} 2 \\
\text { Determination } \\
\text { Coefficient }\end{array}$ & $\begin{array}{c}\text { F } \\
\text { Calculated }\end{array}$ & $\begin{array}{l}\text { Sig* } \\
\text { level }\end{array}$ \\
\hline First & $\begin{array}{c}\text { Information } \\
\text { security }\end{array}$ & 0.699 & 15.556 & 0.000 & 0.600 & 241.987 & 0.000 \\
\hline \multirow[t]{2}{*}{ Second } & $\begin{array}{l}\text { Information } \\
\text { security }\end{array}$ & 0.476 & 9.076 & 0.000 & \multirow[t]{2}{*}{0.686} & \multirow[t]{2}{*}{174.859} & \multirow[t]{2}{*}{0.000} \\
\hline & Software & 0.283 & 6.606 & 0.000 & & & \\
\hline \multirow{3}{*}{ Third } & $\begin{array}{l}\text { Information } \\
\text { security }\end{array}$ & 0.401 & 7.430 & 0.000 & \multirow{3}{*}{0.712} & \multirow{3}{*}{131.177} & \multirow{3}{*}{0.000} \\
\hline & Software & 0.189 & 3.945 & 0.000 & & & \\
\hline & Hardware & 0.247 & 3.800 & 0.000 & & & \\
\hline
\end{tabular}

* The effect is statistically significant at the level $(\mathrm{p} \leq 0.05)$

The results of the stepwise regression analysis show the order of entry of the variables in the regression model that represents the impact of (using o information technology) on (the efficiency of the application of IT governance), as it was found that (information security) came first, and explained (60.0\%) of the variance in the dependent variable, and when adding the (software) in the second model, the interpretation rate increased to (68.6\%), and the addition of (hardware) increased the interpretation rate to (71.2\%). We note that the effect of all independent variables was significant at a significance level less than (0.05).

\subsection{Second Main Hypothesis}

There is no statistically significant effect at the level of significance $(\mathrm{P} \leq 0.05)$ of using information technology (software, hardware, and information security) In organizational flexibility in Jordanian industrial companies.

To test the second major hypothesis, multiple regression analysis was used, and the results were as follows: 
Table 14. * Results of the test of the impact of (using information technology) on organizational flexibility

\begin{tabular}{|c|c|c|c|c|c|c|c|c|c|c|}
\hline \multirow[b]{2}{*}{$\begin{array}{l}\text { Dependant } \\
\text { variable }\end{array}$} & \multicolumn{2}{|c|}{ Model Summery } & \multicolumn{3}{|c|}{ ANOVA } & \multicolumn{5}{|c|}{ Coefficients } \\
\hline & $\begin{array}{c}\mathrm{R} \\
\text { Correlation } \\
\text { coefficient }\end{array}$ & $\begin{array}{c}\text { R2 } \\
\text { Determination } \\
\text { Coefficient }\end{array}$ & $\begin{array}{c}\text { F } \\
\text { Calculated }\end{array}$ & D.f & $\begin{array}{l}\text { Sig } \\
\mathrm{F}^{*}\end{array}$ & Statement & B & $\begin{array}{l}\text { Standard } \\
\text { error }\end{array}$ & $\begin{array}{c}\mathrm{T} \\
\text { Calculated }\end{array}$ & $\begin{array}{l}\text { Sig } \\
\mathrm{t}^{*}\end{array}$ \\
\hline \multirow{3}{*}{$\begin{array}{l}\text { organizational } \\
\text { flexibility }\end{array}$} & & & & & & Software & 0.329 & 0.068 & 4.865 & 0.000 \\
\hline & 0.774 & 0.599 & 79.069 & 3 & 0.000 & Hardware & 0.197 & 0.091 & 2.159 & 0.032 \\
\hline & & & & & & $\begin{array}{c}\text { Information } \\
\text { security }\end{array}$ & 0.355 & 0.076 & 4.665 & 0.000 \\
\hline
\end{tabular}

* The effect is statistically significant at the level $(\mathrm{p} \leq 0.05)$

The results of Table 14 shows that the correlation coefficient $(\mathrm{R}=0.774)$ indicates the relationship between the independent variables and the dependent variable, and the effect of the independent variables (using information technology) on the dependent variable (organizational flexibility) is a statistically significant effect, where the value of Calculated F (79.069), with a significance level $(\mathrm{Sig}=0.000)$ which is less than $(0.05)$, where it appeared that the value of the determination coefficient $\left(\mathrm{R}^{2}=0.599\right)$ indicates that $(59.9 \%)$ of the variance in (organizational flexibility) can be explained by the variance in Dimensions (using information technology) combined.

As for the table of coefficients, it has been shown that the value of B at (software) has reached (0.329) and that the value of $\mathrm{T}$ at it is $(4,865)$, and at the level of significance $(\mathrm{Sig}=0,000)$, which indicates that the effect of this dimension is significant. As for the value of B at (Hardware) has reached (0.197) and that the value of $\mathrm{T}$ at it is (2.159), and at the level of significance ( $\mathrm{Sig}=0.032)$, which indicates that the effect of this dimension is significant. The value of B at (Information Security) was (0.355) and the value of $\mathrm{T}$ at it (4.665), and at the level of significance ( $\mathrm{Sig}=0.000)$, which indicates that the effect of this dimension is significant.

Based on the above, we reject the second main hypothesis and accept the alternative hypothesis: There is a statistically significant effect at the level of significance $(\mathrm{P} \leq 0.05)$ of using information technology (software, hardware, and information security) In organizational flexibility in Jordanian industrial companies.

\subsection{Third Main Hypothesis}

There is no statistically significant effect at the level of significance $(\mathrm{P} \leq 0.05)$ of organizational flexibility in the efficiency of the application of IT governance in Jordanian industrial companies.

To test the Third main hypothesis, multiple regression analysis was used, and the results were as follows:

Table 15. * Results of testing the effect of (organizational flexibility) on the efficiency of the application of IT governance

\begin{tabular}{|c|c|c|c|c|c|c|c|c|c|c|}
\hline \multirow[b]{2}{*}{$\begin{array}{c}\text { Dependant } \\
\text { variable }\end{array}$} & \multicolumn{2}{|c|}{ Model Summery } & \multicolumn{3}{|c|}{ ANOVA } & \multicolumn{5}{|c|}{ Coefficients } \\
\hline & $\begin{array}{c}\mathrm{R} \\
\text { Correlation } \\
\text { coefficient }\end{array}$ & $\begin{array}{c}\mathrm{R} 2 \\
\text { Determination } \\
\text { Coefficient }\end{array}$ & $\begin{array}{c}\text { F } \\
\text { Calculated }\end{array}$ & D.f & $\begin{array}{l}\text { Sig } \\
\text { F* }^{*}\end{array}$ & Statement & B & $\begin{array}{l}\text { Standard } \\
\text { error }\end{array}$ & $\begin{array}{c}\mathrm{T} \\
\text { Calculated }\end{array}$ & Sig $t^{*}$ \\
\hline $\begin{array}{c}\text { The } \\
\text { efficiency of } \\
\text { the } \\
\text { application } \\
\text { of IT } \\
\text { governance }\end{array}$ & 0.785 & 0.615 & 257.692 & 1 & 0.000 & $\begin{array}{l}\text { organizational } \\
\text { flexibility }\end{array}$ & 0.658 & 0.041 & 16.053 & 0.000 \\
\hline
\end{tabular}

* The effect is statistically significant at the level $(\mathrm{p} \leq 0.05)$

The results of Table 15 shows that the correlation coefficient $(\mathrm{R}=0.785)$ indicates the relationship between the independent variable and the dependent variable, and the effect of the independent variable (organizational flexibility) in the dependent variable (the efficiency of application of IT governance) is a statistically significant impact, where The calculated value of $\mathrm{F}$ was (257.692), and at the level of significance ( $\mathrm{Sig}=0,000)$ which is less than (0.05), where it appeared that the value of the determination coefficient $\left(\mathrm{R}^{2}=0.615\right)$ indicates that $(61.5 \%)$ of 
the variance in (efficiency of application of IT governance) can be explained by the variance in (organizational flexibility).

Also, it is clear from the coefficients table that the value of $(\mathrm{B}=0.658)$ and that the value of $(\mathrm{t}=16.053)$ is at a confidence level $(\mathrm{Sig}=0.000)$ and this confirms the significance of the coefficient at the level $(\mathrm{p} \leq 0.05)$.

Based on the above, we reject the third main hypothesis and accept the alternative hypothesis: There is a statistically significant effect at the level of significance $(\mathrm{P} \leq 0.05)$ of organizational flexibility in the efficiency of the application of IT governance in Jordanian industrial companies.

\subsection{Fourth Main Hypothesis}

There is no statistically significant effect at the level of significance $(\mathrm{P} \leq 0.05)$ of the use of information technology (software, hardware, and information security) on the efficiency of the application of IT governance in the presence of organizational flexibility as an intermediate variable in Jordanian industrial companies.

To test the validity of the fourth hypothesis related to direct and indirect impact, Path Analysis was used, using the Amos program and supported by the SPSS program to verify the presence of direct and indirect impact of the study variables.

This hypothesis aimed to define the mediating role of organizational flexibility in the relationship between the dimensions of (using information technology) and the efficiency of the application of IT governance. The results were as follows:

Table 16. Results of the path analysis test to verify the direct and indirect impact of the use of information technology on the efficiency of the application of IT governance in the presence of organizational flexibility as an intermediate variable

\begin{tabular}{|c|c|c|c|c|c|c|}
\hline \multicolumn{7}{|c|}{ Model Fit } \\
\hline Statement & $\begin{array}{c}\text { Chi2 } \\
\text { Calculated }\end{array}$ & D.f & GFI & CFI & RAMSEA & $\begin{array}{c}\text { Sig } \\
\text { level }\end{array}$ \\
\hline The efficiency of the application of IT governance & 13.993 & 3 & 0.991 & 0.982 & 0.061 & 0.000 \\
\hline GFI & \multicolumn{6}{|c|}{ Goodness Fit index } \\
\hline GFI & \multicolumn{6}{|c|}{ Comparative Fit Index } \\
\hline RAMSEA & \multicolumn{6}{|c|}{ Root mean square error of approximation } \\
\hline
\end{tabular}

The results of the statistical analysis in Table 16 showed that the value of $(\mathrm{Chi} 2=13.993)$ is significant, as the level of significance ( $\mathrm{Sig}=0,000)$ is less than $(0.05)$, and the value of chi squared after dividing it by the degree of freedom is equal to (4.664) and is less from the number 5 which indicates the acceptance of the model, and the goodness fit index $(\mathrm{GFI}=0.991)$ and it somehow approaches the number one, as the closer to the correct one this indicates good quality fit, and also the comparative fit index $\mathrm{CFI}=(0.982)$ which It also somehow approaches the number one, and the root mean square error of approximation (RAMSEA $=0.061$ ) which remarkably approaches zero, which supports good agreement model.

Table 17. Direct and indirect impact coefficients for the fourth major hypothesis H04

\begin{tabular}{|c|c|c|c|c|c|}
\hline \multirow[b]{3}{*}{ Path } & \multicolumn{5}{|c|}{ Estimates } \\
\hline & \multicolumn{3}{|c|}{ Direct impact } & \multicolumn{2}{|c|}{ Indirect impact } \\
\hline & $\begin{array}{l}\text { Direct } \\
\text { impact } \\
\text { factor }\end{array}$ & C.R. & $\begin{array}{l}\text { Sig } \\
\text { level }\end{array}$ & $\begin{array}{l}\text { indirect } \\
\text { impact } \\
\text { factor }\end{array}$ & $\begin{array}{c}\text { Sig } \\
\text { level }\end{array}$ \\
\hline Software $\rightarrow$ organizational flexibility & 0.307 & 5.715 & 0.000 & 0.230 & 0.010 \\
\hline Hardware $\rightarrow$ organizational flexibility & 0.388 & 4.302 & 0.000 & 0.290 & 0.010 \\
\hline $\begin{array}{c}\text { Information security } \rightarrow \text { organizational } \\
\text { flexibility }\end{array}$ & 0.481 & 8.270 & 0.000 & 0.360 & 0.010 \\
\hline $\begin{array}{c}\text { Organizational flexibility } \rightarrow \text { the efficiency of } \\
\text { the application of IT governance }\end{array}$ & 0.749 & 25.068 & 0.000 & & \\
\hline
\end{tabular}

Table 17 showed that the direct impact of the software on organizational flexibility has reached (0.307), which is a significant effect, just as the significant direct impact of the Hardware on organizational flexibility reached (0.388), 
while the significant direct impact of information security on organizational flexibility was (0.481). On the other hand, the direct impact of organizational flexibility on the use of information technology has reached (0.749), which is a significant effect, indicating that organizational flexibility positively affects the use of information technology.

The indirect impact of the software on the efficiency of the application of IT governance has reached $(0.230)$ which is a significant effect, while the indirect impact of the Hardware on the efficiency of the application of IT governance was (0.290) is a significant impact, and the indirect impact of information security on the efficiency of the application of technology governance Information (0.360), which has a significant effect as well. And because the direct and indirect impact of each dimension of the use of information technology is a significant effect, organizational flexibility is a partial mediation, and this confirms the existence of a positive role for organizational flexibility as an intermediate variable in the impact of the use of information technology on the efficiency of the application of IT governance when studying the dimensions of using Information technology combined.

Accordingly, it can be said that there is an indirect impact of the dimensions of the use of information technology combined on the efficiency of the application of IT governance with the presence of organizational flexibility as an intermediate variable among Jordanian industrial companies. Therefore, the fourth null hypothesis can be rejected, and the alternative hypothesis which it states is accepted : There is a statistically significant effect at the level of significance $(\mathrm{P} \leq 0.05)$ of the use of information technology (software, hardware, and information security) on the efficiency of the application of IT governance in the presence of organizational flexibility as an intermediate variable in Jordanian industrial companies.

\section{Conclusions}

The results of the analysis of the study data indicated that Jordanian industrial companies' interest in keeping abreast of technological progress and development, integrating information technology in all its activities and operations, and the high level of management's awareness of the role that this technology plays in its various systems, programs, technologies and applications in achieving the competitive advantage of companies by obtaining a large amount of information in a timely manner, which supports their ability to achieve its goals. The results also indicated that the interest of Jordanian industrial companies in applying information technology control tools with a view to activating the contribution of information technology in generating value and ensuring the best efficiency in managing information technology resources and reducing the risks and threats resulting from its use. In addition to that, Jordanian industrial companies have the ability to respond to changes in their internal and external environment, by adopting practices and procedures and allocating the necessary human resources to respond and adapt to these changes. The results of the study indicated that the presence of the effect of using information technology on the efficiency of the application of information technology governance is evidence of the role that information technology plays in managing operations and resources to reach the goals set for the company, and that effective investment in information technology leads to generating value in information technology and improving commercial relations and achieving The goals of using information technology.

The presence of the impact of the use of information technology on organizational flexibility is evidence that Jordanian industrial companies use information technology, systems, software and technologies that they contain in the activities and businesses of companies that help them benefit from the benefits that this technology achieves, thus increasing their ability to respond and interact with events and changes in the work environment. The presence of the impact of organizational flexibility on the efficiency of the application of IT governance is evidence that the response of Jordanian industrial companies to the challenges and developments in their environment requires them to adapt their systems and develop them to obtain the necessary and evident information in a timely manner that contributes to achieving efficiency and effectiveness in the company's performance. The presence of an intermediate effect of organizational flexibility when examining the relationship between the use of information technology and the efficiency of application of IT governance indicates the role of organizational flexibility in activating the dimensions of information technology and its use in achieving efficiency in the application of IT governance.

\section{Recommendations}

Based on the results of the study, the study recommends the necessity of activating the use of information technology based on COBIT 5 in Jordanian industrial companies to increase their contribution to the effectiveness of industrial and production control in them. As well as emphasizing industrial companies to use a leading information network that provides the possibility of the operating and integrated operation of financial, accounting, industrial, and production data. In addition to the necessity to diversify the software that Jordanian industrial companies use to keep abreast of modern developments in information technology at the local and international 
levels. The necessity for Jordanian industrial companies to use modern and advanced processing equipment and equipment to keep pace with international information equipment and devices. In addition to the need to define the powers of the user in Jordanian industrial companies and constantly renew his identity to ensure that he has the powers granted and maintain information security, and finally, the organizational consistency must be established between the uses of information technology in light of the use of COBIT 5 applications and directives in the presence of organizational flexibility, as this will help to adapt With unexpected crises and investment opportunities for industrial companies at the local and international levels.

\section{References}

Ali Osama, Al-tahat Saqer., Al-Duleemi Khaleel, Al-Afeef Jamal., \& Al-hawamdah Hamza. (2019), The Impact of the Decisions of the COBIT 5 Committee on the Effectiveness of the Internal Control Systems in the Jordanian Industrial Joint Stock Companies. The Journal of Social Sciences Research, 5(11), 1587-1599. URL: https://arpgweb.com/journal/journal/7. https://doi.org/10.32861/jssr.511.1587.1599

Al-Kaabi, Hamid Salem., \& Quinn, Abdul-Kazim Mohsen. (2017). The Interactive Role of Administrative Skills in Promoting Strategic Leadership Through Organizational Flexibility -An Exploratory Study of the Views of a Sample of Higher and Middle Administrations in Private Iraqi Banks / Baghdad. Journal of Accounting and Financial Studies, 5(40), 208-228.

Al-Shanti, Ayman Muhammad Nimer. (2011). The role of information technology in developing the profession of auditing: an applied study on auditing offices in the Hashemite Kingdom of Jordan. Journal of Baghdad college of economic sciences university, 27,325-354.

Alshareef, Naser. (2016). A Model for an Information Security Risk Management (ISRM) Framework for Saidi Arabian Organizations. International Conferences ITS, ICEduTech and STE, 365-370.

Bakshi, S. (2017). Portfolio, Program and project Management Using COBIT 5.

El-Rabiti, Lotfi El-Hadi Ali. (2015). The effect of using accounting information technology on the decision-making process in the Libyan National Oil Corporation. Unpublished Master Thesis, Al Al-Bayt University, Mafraq, Jordan.

Guajarati, D.N. (2004). Basic Econometrics. $4^{\text {th }}$ ed., McGraw Hill, New York, US

Haddad, Hussam. (2013). The level of governance of information technology and its impact on the level of financial performance for banks operating in Jordan - a field study using "COBIT5" control targets for information and related technology. Master Thesis, Unpublished, Zarqa University, Amman, Jordan.

Hamad, Saad Ibrahim., \& Saleh, Majed Mohamed. (2018). Information and communications technology and its impact on marketing the tourism service: a field study in a sample of tourism organizations in the governorate of Baghdad. Babylon University Journal, 26(1), University of Babylon, Baghdad, Iraq, 108-107.

Iqbal, A., widyawan., \& Mustika, W. (2016). COBIT 5 domain delivery, service and Support mapping for business continuity plan. https://doi.org/10.1063/1.4953970

Jawad, Abbas Hussein., \& Al-Asadi, Abboud Abdullah. (2010). The impact of information technology on determining the strategic choice of the organization: an applied study in the South Oil Company (a public company). Journal of the College of Administration and Economics, (2), University of Mosul, Mosul, Iraq, 5-125.

Michele, R., FilippoVitolla., \& AntonelloGarzoni. (2017). An empirical examination of cobit as an internal control framework for information technology. International Journal of Accounting Information Systems, 8(4), 240-63. https://doi.org/10.1016/j.accinf.2007.09.001

MutiaraAb, Prihandoko, E., P., \& Widya, C. (2017). Analyzin. COBIT 5 IT Audit Framework Implementation using AHP Methodology. International Journal on Informatics Visualization, 1(2), 33-39. https://doi.org/10.30630/joiv.1.2.18

Okour, Samer. (2019). The Impact of the Application of IT Governance According to (COBIT 5) Framework in Reduce Cloud Computing Risks. Modern Applied Science, 13(7), Published by Canadian Center of Science and Education. https://doi.org/10.5539/mas.v13n7p25

Romero, D., Baldassarre, M., Piattini, M., \& DeGuzman, I. (2017). A Governance and Management Framework for Green IT.

Rommeny, Marshail., \& Stenbart, Paul. (2012). Accounting Information Systems. $10^{\text {th }}$ ed., New Jersey, USA 
Saleh, Walid. (2014). Control over information systems using COBIT. College of Administration and Economics, Anbar University, No. 40, Iraq.

Sekaran, U. (2006). Research Methods for Business. Hoboken, NJ., John Wiley \& Sons.

Zraqat, O. M. (2020). The Moderating Role of Business Intelligence in the Impact of Big Data on Financial Reports Quality in Jordanian Telecom Companies. Modern Applied Science, 14(2), 71-85. https://doi.org/10.5539/mas.v14n2p71

\section{Copyrights}

Copyright for this article is retained by the author(s), with first publication rights granted to the journal.

This is an open-access article distributed under the terms and conditions of the Creative Commons Attribution license (http://creativecommons.org/licenses/by/3.0/). 